\title{
MADDADDAM TRILOGY AS A HISTORICAL CHRONICLE OF THE SILENCED IN A (DYSTOPIAN) SOCIETY
}

\begin{abstract}
The MaddAddam Trilogy includes three novels written in the form of speculative fiction. The narrators and major protagonists in the first two works, Oryx and Crake and The Year of the Flood, are human survivors after the pandemic that has obliterated almost all population on the planet. In these symbolic cautionary tales that reflect current cultural and economic conditions, Margaret Atwood makes readers think about the questions what if mankind was completely eradicated and what if the construction of a new species could be masterminded successfully. In the third book of the trilogy, MaddAddam, the apocalyptic story is retold by one of the genetically engineered beings, whose account provides a glimmer of hope for the future. The aim of this paper is to analyse the roles of the narrators and characters in the aforementioned works (Snowman, Toby, Ren, Adam One and Blackbeard) as recorders of the circumstances before, during and after the tragic event, by relying on Hayden White's theoretical views on the making of historical narratives.
\end{abstract}

KEYWORDS: Margaret Atwood; apocalyptic narratives; emplotment; Oryx and Crake; The Year of the Flood; MaddAddam.

\footnotetext{
maja.cuk@alfa.edu.rs

artea.panajotovic@alfa.edu.rs
}

This paper was submitted on August $29^{\text {th }}, 2020$ and accepted for publication at the meeting of the Editorial Board held on September $25^{\text {th }}, 2020$. 


\section{INTRODUCTION}

The MaddAddam Trilogy is comprised of three novels that depict the cause and the consequences of a biological catastrophe in a dystopian setting. In Oryx and Crake, the story is told by Jimmy the Snowman, the guardian and "the prophet" of the Crakers - genetically engineered humanoids from the laboratory of his friend Crake, a scientist whose drug wiped out the majority of the human race. The second book, The Year of the Flood, focuses on the lives and viewpoints of the members of the God's Gardeners cult, Toby, Ren and Adam One, who are among the few survivors after "The Waterless Flood". It is interesting that in the third part, the story about the threats that have almost extinguished mankind is not narrated by a man or a woman: one of the aforementioned bioengineered creatures, Blackbeard, presents his own "manuscript" about the events after the pandemic. The aim of this paper is to analyse the function of the marginalized narrators and protagonists in The MaddAddam Trilogy and their roles as "the historians" whose accounts, in a symbolic way, reflect the political landscape of the first decades of the $21^{\text {st }}$ century, by relying on Heyden White's theoretical perspectives on creating history.

Even though The MaddAddam Trilogy is indubitably part of the dystopian tradition, ${ }^{3}$ Margaret Atwood's characters break through the traditional plots and characterization of dystopias and classics into their own stories. In classic dystopian novels, Huxley's, Orwell's and Burgess's works, the major protagonist is usually a (white) Man,

Sarah A. Appleton finds the following parallels between the first book of The Maddaddam Trilogy and other dystopian novels:

"To offer but a small sampling of the dystopian allusions replete within the narrative, Jimmy's sense of being watched by the corporation/government summons up George Orwell's 1984, and Atwood's “pigoons" are infused with Orwellian imagery from Animal Farm. The sexual complacency of women in Oryx and Crake harkens to Huxley's Brave New World, as do certain Freudian references, particularly about motherhood. The scientific fabrication of a sentient being has its roots in Mary Shelley's Frankenstein, Marge Piercy's He, She, and It, and Phillip Dick's "Do Androids Dream of Electric Sheep?" Ideas about the destruction of humanity can be found in On the Beach as well as Stephen King's The Stand, and it is the motif of dozens of popular films and video games. Jimmy's portrayal of two different versions of dystopia can be seen in Marge Piercy's Woman at the Age of Time, contrasting the edenic and hellish possibilities of different planes of existence, as well as Ursula Le Guin's The Left Hand of Darkness" (Appleton, 2008, p. 11) 
while female characters or members of other races are not given the role of "carriers" of literary messages. In our analysis of The MaddAddam Trilogy we will show how Margaret Atwood, as "a feminist postcolonialist" (Wilson, 1993, p. 28), gives voice to the silenced and shifts the point of view to the unreliable, unprivileged and even highly unusual centres of consciousness and narration, exposing issues of power politics, social, sexual and religious orthodoxy and the possibility of the survival and evolution of mankind.

Heyden White claims that the presentations of historical events in chronicles bear resemblance to the narrative strategies in literature. Similar techniques of "emplotment" are used in both disciplines:

"The events are made into a story by the suppression or subordination of certain of them and the highlighting of others, by characterization, motific repetition, variation of tone and point of view, alternative descriptive strategies, and the like - in short, all of the techniques that we would normally expect to find in the emplotment of a novel or a play. For example, no historical event is intrinsically tragic; it can only be conceived as such from a particular point of view or from within the context of a structural set of events of which it is an element enjoying a privileged place" (White, 2001, p. 1715).

According to this scholar, writing a historical chronicle is a socially responsible deed, but it is not an impartial act. Certain circumstances occurred at a certain time and place, but the historian is the one who supplies meaning in the particular context. Therefore, neither historical chronicles nor other narratives are "an innocent representation of raw facts" (White, 1987, p. 176), but (un)conscious selection, simplification and organization of relevant data according to the subjective criteria or the predominant ideology of the time:

"Histories, then, are not only about events but also about possible sets of relationships that those events can be demonstrated to figure. These sets of relationships are not, however, immanent in the events themselves; they exist only in the mind of the historian reflecting on them. Here they are present as the modes of relationships conceptualized in the myth, fable, and folklore, scientific knowledge, religion, and literary art, of the historian's own culture" (White, 2001, p. 1724).

Since a historian weaves his/her personal beliefs and feelings into the details of the recorded event, "it is difficult to get an objective history of a scholarly discipline", according to White (2001, 
p. 1712). Similarly to a literary work, a historical narrative is also "a symbolic structure" which "does not reproduce the events it describes," but tells us "in what direction to think about the events and charges our thought about the events with different emotional valences" (White, 2001, p. 1721). As White notes, a historian is above all "a story teller" (White, 2001, p. 1714) and his/her works are "translations of fact into fiction" (White, 2001, p. 1722). He corroborates his views by R.G. Collingwood's claims that "historical sensibility was manifested in the capacity to make a plausible story out of a congeries of "facts" which, in their unprocessed form, made no sense at all" (White, 2001, p. 1714). The proper understanding of the truth behind a particular "action" in history depends on the suppressed meaning and subtext: "Our explanations of historical structures and processes are thus determined more by what we leave out of our representations than by what we put in" (White, 2001, p. 1721).

What and why is not included in the mainstream narratives of the dystopian society in The MaddAddam Trilogy, how suppressed tales find a way to be told or written and who are "the historians" of the new civilization in these books are some of the questions we will deal with in our analysis, through the lens of White's theory.

\section{ORYX AND CRAKE}

In Oryx and Crake, the narrator and protagonist Snowman, whom the readers believe to be the only survivor of mankind after the apocalypse, assumes the role of a preacher and a historian in a peculiar "society". Apart from him, the only inhabitants of the new world are young Crakers, unusual creatures created in an artificial way. These "amazingly attractive" (Atwood, 2003, p. 8) and peaceful herbivorous humanoids, who have been designed to have sexual intercourse only during limited breeding seasons, were supposed to replace the destructive and environmentally harmful people.

Snowman paints the picture of the pre-apocalyptic cultural climate through flashbacks about his childhood and youth in a posh sector where the privileged families of the powerful corporations' employees lived. The bio-corporations' business included genetic splicing of animals and engineering "products," such as rakunk (a genetic splice between a raccoon and a skunk) or a pigoon, genetically engineered pig which produces organs for human transplants. 
All activities were controlled by CorpSeCorps corporate security services. Neglected by his parents who were busy working at OrganInc or preoccupied with their own worries, Jimmy (which is Snowman's real name) spent his teenage years smoking "skunkweed," playing online games with ominous names and contents like Extinctathon, watching bizarre footages like live executions, child pornography, etc. In a society which favourized analytical discourse, rational arguments and scientific methods, Jimmy couldn't argue his point of view and needed to retreat "into one word utterances or silence" (Osborne, 2008, p. 30).

The only true friend and brother figure in Jimmy's life, with whom he shared the same interests and the love for the same woman - Oryx, was a gifted science student Glenn, nicknamed Crake after the pseudonim he used in the aforementioned online games. As a prominent bioengineer at RejoovenEsense, after attending the respected Watson-Crick Institute, Crake designed the BlyssPluss pill, a harmful tool in his plan to cause sterility and a global pandemic, which was advertised as a healthy and empowering supplement and widely distributed around the globe. Disgusted and disappointed by the society which had become too pragmatic about the morality of genetic engineering, blinded by consumerism, indifferent to child abuse and too cruel to the suspected enemies of the system, Crake developed a new form of Homo Sapiens to replace the corrupted humans. His "final products", Crakers, seem to be impeccable:

"They're every known colour from deepest black to whitest white, they're various heights, but each one of them is admirably proportioned. Each is sound of tooth, smooth of skin. No ripples of fat around their waists, no bulges, no dimpled orange-skin cellulite on their thighs. No body hair, no bushiness. They look like retouched fashion photos, or ads for a high-priced workout program" (Atwood, 2003, p. 100)

While Crake decided to improve mankind by creating beings without physical anomalies and by eradicating negative characteristics from genes in a scientific way (greed, malice, envy, etc.), Snowman seems to test another approach as a corrective measure for the fallen state of people - mending the spiritual instead of physical aspect, by creating a new story about the past for the Crakers. Although he is constantly haunted by the painful memories of his old life, he does his best to take care of the Crakers in his distress, after the pandemic and Crake's and Oryx's deaths. Although 
at first he sees interactions with Crakers "more of a burden, than a comfort" (Osborne, 2008, p. 27), the encapsulation of his and his friends' life stories into the format of "a historical chronicle," on the verge of a mythological narrative and legend, will actually help him to "emerge from his current disillusionment, self-doubt and resignation" (Osborne, 2008, p. 27). Demonstrating that neither mythological and religious texts, nor historical accounts are "an innocent representation" of data, "the historian" in Oryx and Crake selects, simplifies and organizes the facts from the past in the way he finds suitable.

Through Snowman's "playing with religious concepts and the specific postmodern theogony" (Cuk, 2014, p. 19) in his interaction with the Crakers, Atwood challenges the accountability of historians, authors of Holy Scripts, men of letters and everyone who is given the responsibility of passing the knowledge of the past to the future, drawing attention to the power of words and narratives. While his affinity for language and the arts was not appreciated in the world of his youth dominated by science, his wordplays and adjusted scenarios in post-apocalyptic setting lay the foundations for a new history, religion, and social organization. In his "emplotment" and a(n) (un)conscious establishment of an innovative system of belief and moral, Snowman mentions "the chaos", where "people were all mixed up with the dirt" and were killing each other in the old governing structures, as a cautionary tale (Atwood, 2003, p. 102). However, in his retelling of the past, the inconvenient events from his own biography or the infamous details about the life of his beloved are left out, starting from Oryx's involuntary involvement in the pornographic industry after she was "sold" as a child (Atwood, 2003, p. 116), to his quarrel with Crake and deadly shooting after Crake found out about Jimmy and Oryx's affair, etc.

Snowman presents Crake as a God who "came down out of sky, as thunder" (Atwood, 2003, p. 104), masterminded "The Great Rearrangement" (Atwood 2003, p. 104) and "made the bones of the Children of Crake out of coral on the beach, and then he made their flesh out of a mango" (Atwood, 2003, p. 96). Oryx, who produced and educated the Crakers, is depicted as a Goddess who laid "a giant egg" out of which the Crakers hatched, along with animals, birds, fish and words (Atwood, 2003, p. 96). His "historical chronicle" abounds with happy feelings and the emphasis of virtues which should strengthen collective spirit: 
"The Crakers recognize that the "bad things" (103) that occurred in chaos, murder and the unnecessary taking of animal life, are to be avoided. Through his presentation of Oryx and Crake as deities, Snowman has established the primacy of love; building on the qualities programmed into these beings and the lessons already given by Oryx, Snowman's stories reinforce the Crakers' respect for all life and for the natural environment. When they do kill a fish for Snowman to eat, they act together so that no one person assumes all the guilt, thus reinforcing communal spirit. They have even been trained to recycle the leftovers from Snowman's meals." (Osborne, 2008, p. 40)

Unlike the advertising industry in which he worked after Martha Graham Academy, where language was used as a tool of manipulation for not particularly good causes, in the accounts for the Crakers Jimmy puts his love of words to good use. ${ }^{4}$ In the old world, the meaning of words was secondary to the effect they produce on the buyers, and images and language were manipulated by the media to the point where it was impossible to find out what is real and what has actually happened:

"In Jimmy's world, the imaginative arts have suffered from neglect and abuse. The manner in which the culture perverts art and preys on language is symbolized by the Vulture Sculptures created by Amanda, Jimmy's girlfriend at Martha Graham: she creates the shapes of words out of dead animals parts and then photographs the scene as vultures attack." (Osborne, 2008, p. 37)

The pre-pandemic society, where Jimmy felt as a misfit, saw little value in the talents and professions connected with the writing.

\section{THE YEAR OF THE FLOOD}

In the first book of The MaddAddam Trilogy, the narrator and most protagonists involved in the stories before "The Waterless Flood"

4 It is interesting to note that he is undergoing a sort of "linguistic deprogramming" (Osborne 2008, p. 37) in the process: In communicating with the childlike Crakers he needs to process his use of language, making certain that for each word he says, there is a reference in their experience:

They follow each motion, enthralled. "No," he says. "Crake says you can't. No feathers for you. Now piss off."

"Piss off? Piss off?" They look at one another, then at him. He's made a mistake, he's said a new thing, one that's impossible to explain. Piss isn't something they'd find insulting. "What is piss off?" (Atwood, 2003, p. 9) 
belong to the upper class of the society. However, in its sequel, The Year of the Flood, Atwood puts the voice of the lower class at the center of the story, presenting the "other side" of the tale which started in Oryx and Crake. In deconstructing the classic pattern of a dystopia, allowing the silenced subtext to speak, Atwood's metanarratives here consist of three narrative strands interwoven in dialectic with one another. The same method is used in her rewriting of fairy tales and mythic intertexts which includes "the frame narrative" and "the embroidered intertexts, usually heightened, exaggerated, or parodied" (Wilson, 1993, p. 31). The muted protagonists and "the victims" of ideological bias, Toby, Ren and Adam One conceive a different view of the world in their accounts. While, as we have seen in Oryx and Crake, employees of the multinational corporations which wield a dangerous amount of power live in luxurious compounds with a range of facilities and a vast amount of money is invested in the scientific advancement and new forms of transgenic research, the unprivileged people live in poor circumstances in neighborhoods called "pleeblands".

In such a world, governed by materialistic values and goals, people are treated as commodities and "devoured" by the system or influential persons. At a particular moment in her life, after all family tragedies (the loss of her mother, her father's suicide, etc.), Toby, one of the protagonists of the second book of The MaddAddam Trilogy, starts working at a burger chain called SecretBurgers. An odd characteristic of this establishment is the open secret that meat in its meals contains not only dead cats, rats and dogs, but also humans' parts. This "cannibalistic" approach is not confined to the company's products, but represents the general attitude and behavior of Toby's psychopathic manager Blanco, whose possession she becomes:

"The office was through a grimy door tucked behind a carbon garboil dumpster. It was a small room with a desk, filing cabinet, and battered leather couch. Blanco heaved himself out of his swivel chair, grinning.

"Skinny bitch, I'm promoting you," he said. "Say thank you."

Toby could only whisper: she felt strangled.

"See this heart?" said Blanco. He pointed to his tattoo. "It means I love you. And now you love me too. Right?"

Toby managed to nod.

"Smart girl," said Blanco. "Come here. Take off my shirt" 
The tattoo on his back was just as Rebecca had described it: a naked woman, wound in chains, her head invisible. Her long hair waving up like flames.

Blanco put his flayed hands around her neck. "Cross me up. I'll snap you like a twig," he said." (Atwood, 2009, p. 37).

The illustrations of the events in Toby's life and her comments hold a mirror up to all absurdities and injustice in her society and her time. She is lucky that Adam One, the founder of God's Gardeners, manages to convince her to run away and come to live in their community.

Important passages of the book are the parts of God's Gardeners' teachings preached by their leader, Adam One. This eco-sect is warning against the apocalypse that will drown mankind, so they prepare and supply their shelter for after the flood arrives in the hidden storeplaces called Ararats (Atwood, 2009, p. 312). Adam One's "chronicle" is created out of dissatisfaction with the polluted, polarized, and materialistic society where his voice was silenced. In his "sermons", he transgresses the convention of religious texts, by selecting, reshaping and processing particular motifs from the Bible in the context of scientific discoveries. Anticipating the coming of the natural disaster that is going to come to obliterate the humans so that the Earth can recover from the damaging effects of technology, Adam One and his followers draw attention to the necessity to appreciate all plant and animal life on the planet:

"What commandment did we disobey? The commandment to live the Animal life in all simplicity - without clothing, so to speak. But we craved for knowledge of good and evil, and we obtained the knowledge, and now we are reaping the whirlwind. In our efforts to rise above ourselves we have indeed fallen far, and are falling farther still; for, like the Creation, the Fall, too, is ongoing. Ours is fall into greed: why do we think that everything on Earth belongs to us, while in reality we belong to Everything? We have betrayed the trust of the Animals, and defiled our sacred task of stewardship. God's commandment to "replenish the Earth" did not mean we should fill it to overflowing with ourselves, thus wiping out everything else. How many other Species have we already annihilated?" (Atwood, 2009, p. 52)

In his "sermons", which are slightly infused with irony and satire by Atwood, the charismatic "holy man" melds religion with science: 
"God could have made Man out of pure Word, but He did not use this method. He could also have formed him from the dust of the Earth, which in a sense He did, for what else can be signified by "dust" but atoms and molecules, the building blocks of all material entities? In addition to this, He created us through the long and complex process of Natural and Sexual Selection, which is none other than His ingenuious device for instilling humility in Man. He made us "a little lower than the Angels," but in other ways - and Science bears this out - we are closely related to our fellow Primates, a fact that the haughty ones of this world do not find pleasant to their self-esteem. Our appetites, our desires, our more uncontrollable emotions - all are Primate!" (Atwood, 2009, p. 52).

The same literary approach is used in their hymns from The God's Gardeners Oral Hymnbooks that are also inserted in the book as a significant testimony about the cult's creed. For example, in "My Body Is My Earthly Ark," "genes", "cells", "neurons" have been mentioned along with "Ark", "the Flood", "Spirit's guide" and "the Creator's praise" (Atwood, 2009, p. 93). Adam One is depicted as "the creator" of a new religion where the motifs from Old and New Testaments are interpreted and rewritten through the lens of the socio-cultural factors of the time. Offering his views as "anchors of hope," in his "gospels" of a dystopian society, God's Gardeners' leader provides an atmosphere for redemption and "second chance" for the individuals who have found peace in their community and the whole planet alike.

Toby, an insightful "historian" of pre-pandemic and post-pandemic world, is also a perceptive recorder of God's Gardeners' life and their pacifist teachings. Her narrative offers a different perspective on their beliefs and approaches and raises pertinent questions about their unusual, sometimes contradictory teachings. Even though their "sermons" are intertwined with ecological and scientific knowledge, as well as didactic texts from the Bible, Toby notices that the Gardeners are not eager to provide constructive answers to her questions:

"By now she was used to the dark, sack-like garments the women wore. "You'll want to grow your hair," said Nuala. "Get rid of that scalped look. We Gardener women all wear our hair long." When Toby asked why, she was given to understand that the aesthetic preference was God's. This kind of smiling, bossy sanctimoniousness was a little too pervasive for Toby, especially among the female members of the sect." (Atwood, 2009, p. 46) 
A lot of details are hidden, Toby's attempts to discover the truth are often futile and she remains curious about many facts:

"Where had Marushka Midwife learned her skills? What exactly had Adam One done before the Gardeners? Had there ever been an Eve One, or even a Mrs. Adam One, or any child Adam Ones? If she came too close to such territory Toby would be granted a smile and a change of subject, and a hint that she might try avoiding the original sin of desiring too much knowledge, or possibly too much power. Because the two were connected - didn't dear Toby agree?" (Atwood, 2009, p. 102)

Only a few members of the cult are familiar with the facts that the Gardeners possess a laptop in a secret room or that Pilar did not make "a species identification error" (Atwood, 2009, p. 183) and die of mushroom poisoning, as Adam One has explained in "a lying speech" (Atwood, 2009, p. 183), but that she committed suicide. At the general Gardeners' meeting following this incident, Adam One apologizes to Toby for his "excursion into fiction" and explains that he "must sometimes say things that are not transparently honest," because "it is for the greater good" (Atwood, 2009, p. 184). As we can see, Toby doesn't blindly accept every aspect of the Gardeners' creed, and she is even prone to criticizing particular practices.

While she is not enthusiastic about some elements of their religion, Ren, who joins the Gardeners two years after Toby, strongly dislikes her life there and provides yet another perspective on the cult. Although Gardeners "smiled a lot," they scared her (Atwood, 2009 , p. 59). Their interest in doom and death is repulsive:

\footnotetext{
"Not everyone might think that having your body become part of a vulture was a terrific future to look forward to, but the Gardeners did. And when they'd start talking about the Waterless Flood that was going to kill everybody on Earth, except maybe them - that gave me nightmares." (Atwood, 2009, p. 59)
}

This protagonist is brought to become a member of the cult by her mother Lucerne who has left a corporate compound in order to start a new life with her partner Zeb, "Adam Seven" in the hierarchy of the Gardeners' council, who will be one of the major characters in MaddAddam. One of Ren's commentaries, which are not in favour of the logic of the Gardeners' principles, is that "they'd tell you to do something and then prohibit you the easiest way to do it" (Atwood, 2009, p. 68). It is also interesting that the younger members of the cult do not respect the elders in a way you might expect. 
They would coin ugly nicknames for their teachers (Wet Witch, Dry Witch), and even Zeb whom they call Mad Adam.

In her teenage years, Ren leaves the Gardeners' community, falls in love with Jimmy who breaks her heart and attends Martha Graham Academy for a while before Toby recruits her to help her in the AnnooYoo Spa where she has been sent by the Gardeners to work in disguise. Wanting "no strings, no past, and no questions asked" (Atwood, 2009, p. 301), after she gets extremely disappointed when she finds out that her best childhood friend Amanda is dating Jimmy, Ren leaves her job. Hoping that she would be more appreciated in the Club Scales and Tales, she becomes a sex worker and a trapeze dancer, unaware of the fact that she is also being sexually abused by her bosses, in a similar way as Oryx (Atwood, 2003, p. 90). This girl is led to believe that she is protected and actually "very lucky" (Atwood, 2009, p. 6) to work there:

"Scales and Tails took care of you, they really did. If you were talent, that is. Good food, a doctor if you needed one, and the tips were great, because the men from the top Corps came here. It was well run, though it was in a seedy area - all the clubs were." (Atwood, 2009, p. 7)

Standing up for the girls who are treated as "a valuable asset, he'd say" (Atwood, 2009, p. 7) was "a point of honour with him" (Atwood, 2009, p. 7), because "he had ethics" (Atwood, 2009, p. 7), as she describes the owner of the place Mordis.

Although Ren might seem to be naïve, she knows in what system she is living. Commenting on the pandemic which has started as a "minor epidemic" and then becomes "an eruptive plague" (Atwood, 2009, p. 283), she notices:

"Ordinarily the Corps would have called for lies and cover-ups, and we'd hear something like the real story only in rumours, so the fact all this was right out there on the news showed how serious it was the Corps couldn't keep the lid on." (Atwood, 2009, p. 283)

In her sentimental recollections of the past, Ren also evokes Amanda's outdoor art landscape installation series called The Living Word, which was mentioned in Oryx and Crake, and how her friend "was spelling words out in giant letters, using bioforms to make the words appear and then disappear, just like the words she used to do with ants and syrup when we were kids" (Atwood, 2009, p. 304). Similar to the discussed marginalized and silenced protagonists, Jimmy, Toby and Adam One, Ren couldn't live up to the ex- 
pectations of their society and realize her full potential, but she has succeeded to leave a mark by her telling observations about dogmatic views, stereotypes, polarization and abuse in her "historical testimony".

\section{MADDADDAM}

In the third book, MaddAddam, Atwood displaces the plotline narrated by the humans, so that the silenced subtext of the Crakers' experience is central. After Jimmy the Snowman's illness and death, Toby takes on the role of a spirit guide and a teller of stories from the old world, and her personality and speech make a huge impact on the little Craker called Blackbeard, influencing the formation of his identity as a spiritual leader and a historian of his community. The narrator of MaddAddam, Blackbeard starts to observe the main protagonists Toby and Zeb and a few more humans in the group of survivors. He is a precocious and ambitious boy who likes to be taught useful skills by people so that he can pass them on to the next generations of Crakers, members of the new race: "There," says Blackbeard, "Telling the story is hard, and writing the story must be more hard. Oh Toby, when you are too tired to do it next time I will write the story. I will be your helper" (Atwood, 2013, p. 375).

Thus, in the third book of The MaddAddam Trilogy, one of the carefully crafted Crakers is acting as the creator of the post-apocalyptic history and the founder of a new religion: "I am putting on the red hat of Snowman-the-Jimmy. See? It is on my head. And I have put the fish into my mouth, and taken it out again. Now it is time to listen, while I read to you from the Story of Toby that I have written down at the end of the Book" (Atwood, 2013, p. 388). His text is a combination of the entries of Toby's diary, her tales and experience on the one hand, and his own impressions of what is happening at the time on the other. Apart from presenting a ray of hope for the planet at the end of the novel, Blackbeard describes the circumstances in which a new race is created in unusual relationships between humans and Crakers.

At the beginning of MaddAddam Toby summarizes "the theogony" and "the cosmology" which Snowman-the-Jimmy narrated in Oryx and Crake. She is telling the Crakers about the Egg where Crake made them, which "was big and round and white, like half a bubble, 
and there were trees inside it with leaves and grass and berries" (Atwood, 2013, p. 3). Toby reminds them of the chaos outside the Egg where bad people did "cruel and hurtful things to one another, and also to the animals" (Atwood, 2013, p. 3).

In MaddAddam, Blackbeard is a Craker sociologist and anthropologist of his time who analyses and describes habits, interests and feelings among people, the relations and relationships between humans and Crakers, the attitude and cooperation between the survivors and other living things and the establishment of the posthuman world order. ${ }^{5}$

Apart from his anthropological survey and biblical-like stories about Oryx and Crake and "new Eden", Blackbeard's text incorporates "the legend" about Zeb, who is Toby's boyfriend and the brother of Adam One, the founder of the God's Gardeners. As a matter of fact, at the very end of the novel Blackbeard presents Toby's death and the conclusion of Toby and Zeb's love story as a legend:

"Yet others say that she went to find Zeb, and that he is in the form of a Bear, and that she too is in the form of a Bear, and is with him today. That is the best answer, because it is the happiest; and I have written it down. I have written down the other answers too. But I made them in smaller writing." (Atwood, 2013, p. 390)

Although as a child he lacks the linguistic sophistication of the first "historians" of post-apocalyptic society, Blackbeard learns to carefully choose and process the historical trails left behind in written form and to concoct easily the most appropriate plots, in a similar way his predecessors Snowman, Toby, Ren and Adam One did.

At the end, Blackbeard also informs us that three Beloved Oryx Mothers, Ren, Amanda and Lotis Blue, who give births to "a green-eyed Craker hybrid" (Atwood, 2013, p. 380), "cried very much when Toby went away" (Atwood, 2013, p. 390). Apart from his

He even leaves records of how the survivors are dressed in the cob-house enclave, their shelter, and the settlement where they actually need to wear sheets and towels, because of the lack of clothing items. Ivory Bill, one of the men in the group, is even using a pillowcase as a hat: "He has a tulip-sprinkled bedsheet draped around his sparse form and a turban-like object made from a matching pillow case on his head (Atwood, 2013, p. 42). For the Crakers, humans have "an extra skin" (Atwood, 2013, p. 42), while on the other hand, they are naked. As it has been already mentioned, Crake's humanoids have shaped bodies with perfect proportions, without any physical defects. 
best friend's and role model's death, there are good news in Blackbeard's "gospel":

"Then Swift Fox told us that she was pregnant again and soon there would be another baby. And the fourfathers were Abraham Lincoln and Napoleon and Picasso and me, Blackbeard, and I am very happy to have been chosen for that mating. And Swift Fox said that if it was a girl baby it would be named Toby. And that is a thing of hope." (Atwood, 2013, p. 390)

Despite Toby's warning to Zeb that "hope can ruin you" (Atwood, 2013, p. 160), her student shows that he is capable of identifying hope as a positive feeling with which he decides to end his story. In this way, even though the Crakers are represented as beings programmed to be docile and incapable of understanding a wider range of emotions, ${ }^{6}$ Blackbeard proves that they are able to recognize emotions, to grow attached and to love someone, to feel proud and to have the urge to leave a trace of their existence on the planet, through writing or in other ways. Therefore, the Crakers, considered to be "other beings" at the beginning (Osborne, 2008, p. 41) do not appear to be different from humans, from a spiritual aspect, in the end.

CONCLUSION All narrators in The MaddAddam Trilogy originate from a society that has elevated the sciences and where the arts and humanities do not seem to be important. The construction of their own scripts has proved to be instructive for the members of a new society and has shown that words also have a special and significant role within every civilization. Filtered and reshaped like Heyden White's historical chronicles, the products of their "emplotment" represent means to alleviate the injustice or stereotypes inflicted on them and to destabilize the prevailing narratives of a bygone age. As creative and spirited "historians" and storytellers of an imaginary dystopian scenario with a happy ending, they seem worthy vessels for Atwood's hopes about mankind.

6 Their questions about particular unfamiliar concepts, asked in a childish manner, might seem comic:

"What does the pain taste like, Oh Toby"

"Should we eat the pain too?"

"If we ate the pain, that would help Snowman-the-Jimmy"

"The pain smells very bad. Does it taste good?" (Atwood, 2013, p. 22) 
Although Snowman and his inclinations towards humanity were devalued and discredited by his contemporaries, he becomes a respectful "preacher" who can mold a creative historical chronicle that will guide the Crakers and the people who have survived the pandemic in building their future. The symbolic "gospels" - the account of Toby's life, Ren's memories and commentaries about the past and the present and Adam One's sermons - draw attention to the adverse consequences of technological advancement, "cannibalistic" nature of consumerism and a dangerous "diminishment of human morals", warning people that they should mend their ways (Ćuk, 2013, p. 323). The last narrator in the trilogy, Blackbeard, succeeds to rise above the Crakers' straightforward use of language, defining himself as a distinguished man of letters who can supply meaning and fashion his own anthropological surveys: "This is my voice, the voice of Blackbeard that you are hearing in your head. That is called reading. And that is my own book, a new one for my writing and not the writing of Toby" (Atwood, 2013, p. 371).

Through the symbolic "historical chronicles" of the marginalized and inappropriately silenced narrators and protagonists in The MaddAddam Trilogy, Atwood sensitizes readers to the problems of polarization, social injustice, gender inequality and human trafficking, which are not only the disturbing social forces in a dystopian novel, but the reflection of our reality. As fictional characters, Snowman, Toby, Ren and Adam One serve as the "historians" of "The Waterless Flood" for the Crakers and human survivors. As someone who, in a symbolic way, through their "testimonies", alerts people to the "plagues" of the society nowadays, Atwood functions as ours.

Appleton, S. A. (2008). Mythmaking in Margaret Atwood's Oryx and Crake. In: S. A. Appleton (edt.) Once upon a Time: Myth, Fairy Tales and Legends in Margaret Atwood's Writing (9-23). UK: Cambridge Scholars Publishing.

Atwood, M. (2003). Oryx and Crake. New York: Nan A. Talese an imprint of Doubleday.

Atwood, M. (2009). The Year of the Flood. London: O.W. Toad.

Atwood, M. (2013). Maddaddam. London: O.W. Toad.

Ćuk, M. (2013). Godina potopa: preispitivanje vrednosti kroz biblijske mitove u prozi Margaret Etvud. U: V. Lopičić i B. Mišić Ilić (prir. i ur.) Jezik, književnost, vrednosti (315-323). Niš: Filozofski fakultet, 2013. 
Osborne, C. (2008). Mythmaking in Margaret Atwood's Oryx and Crake. In: S. A. Appleton (edt.) Once upon a Time: Myth, Fairy Tales and Legends in Margaret Atwood's Writing (25-46). UK: Cambridge Scholars Publishing.

Wilson, S. R. (1993.) Margaret Atwood's Fairy-Tale Sexual Politics. Jackson: University Press of Mississipi.

White, H. (1987). The Content of the Form. Baltimore and London: Johns Hopkins University Press.

White, H. (2001). The Historical Text as Literary Artifact. In: V. B. Leitch (ed.) The Norton Anthology of Theory and Criticism (1709-1729). New York: W.W. Norton\&Company Ltd.

Ћук, М. (2014). Улога религије и митологије у роману Анӣuлойа и Косаu. У: А. Прњат и Т. Парезановић (прир. и ур.) Језик, књижевносй и релиіија (7-20). Београд: Алфа Универзитет, 2014.

МАЈА М. ЋУК

АРТЕА Д. ПАНАЈОТОВИЋ

АЛФА БК УНИВЕРЗИТЕТ

ФАКУЛТЕТ ЗА СТРАНЕ ЈЕЗИКЕ

САЖЕТАК

\section{ТРИЛОГИЈА ЛУДАДАМ КАО ИСТОРИЈСКА ХРОНИКА ОБЕСПРАВЉЕНИХ У (ДИСТОПИЈСКОМ) ДРУШТВУ}

Трилогија ЛуgАgам обухвата романе Анӣuлоӣa и Косаи, Гоgина ӣoūoūa и ЛygAgaм, који описују узроке и последице смртоносног вируса у дистопијском контексту. Наратор првог поменутог дела је Снежни, пријатељ научника Косца, који је изазвао пандемију у којој је изумрла готово читава популација на планети. Овај протагониста преузима улогу заштитника и ствараоца другачијег историјског поретка за Кошчиће, генетским инжењерингом створена бића ठеспрекорног изгледа и карактера лишеног негативних осећања и нагона карактеристичних за људску врсту. У другом делу трилогије о околностима пре и након апокалипсе говоре Тоби, Рен и Адам Један, следбеници култа Божји баштовани, који упозоравају човечанство на апокалипсу, као последицу урушавања вредности и непримереног односа према природи. У трећем делу се о стварању нове цивилизације говори из перспективе једног од Кошчића, Црнобрадог, који својим лингвистичким компетенцијама не заостаје за поменутим хроничарима ове епохе из људске расе. Циљ овог рада је да се преи- 
спита улога поменутих протагониста и наратора као утемељивача другачијих историјских хроника у односу на стари систем вредности пре катастрофе, ослањајући се на теоријска виђења Хејдена Вајта у вези са конструкцијом историјских наратива. У претходном уређењу и друштву пре „потопа“, кључну улогу су имали наука и технолошки развој, као и тежња ка материјалним добрима и маргинализовању сваког ко би испољавао другачије принципе у односу на владајућу идеологију. Занимљиво је да, кроз симболичне „историјске хронике“ поменутих ликова, Маргарет Етвуд скреће пажњу читаоцима на проблематику класних, родних и религиозних подела у друштву, као и злоупотребу медијских садржаја и експлоатацију људи, што нису само узнемиравајући мотиви у дистопијској прози већ забрињавајуће околности наше свакодневице. Кроз њихово прекрајање догађаја и пракси из прошлости, из перспективе gpyīoi, тј. обесправљених појединаца у (дистопијком) друштву, показује се како и колико су за опстанак једне цивилизације и грађење квалитетне будућности важни и духовна надградња и таленат да се у писаним сведочанствима оставе адекватне и конструктивне смернице за нове генерације.

КљУчНЕ РЕчИ: Маргарет Етвуд; дистопијски наратив; Анӣuлоӣa u Косаи; Гоgина йō̄oūa; ЛygАgам.

Овај чланак је објављен и дистрибуира се под лиценцом Creative Commons Ауторство-Некомерцијално Међународна 4.0 (CC BY-NC 4.0 |

https://creativecommons.org/licenses/by-nc/4.0/).

This paper is published and distributed under the terms and conditions of the Creative Commons Attribution-NonCommercial International 4.0 licence (CC BY-NC 4.0 | https://creativecommons.org/licenses/by-nc/4.0/). 